\title{
Incorrect description of mode of excretion of linagliptin
}

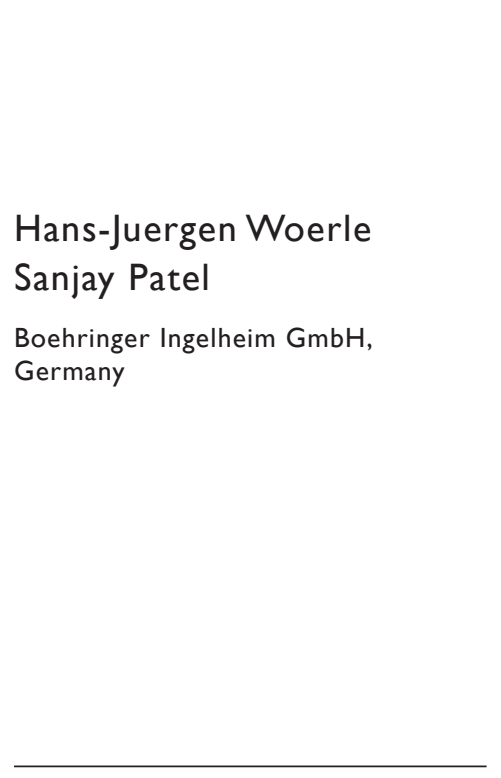

Correspondence: Sanjay Patel

Boehringer Ingelheim $\mathrm{GmbH}$, Binger Strasse 173, 55216 Ingelheim am Rhein, Germany

Tel +44 I 344 74-I 258

Fax +44 I344 74- I772

Email sanjay.patel@boehringer-ingelheim. com

\author{
This article was published in the following Dove Press journal: \\ Drug, Healthcare and Patient Safety \\ 27 May 2010 \\ Number of times this article has been viewed
}

\begin{abstract}
Dear Dr Zhou,
Boehringer Ingelheim, owner of the investigational drug linagliptin, would like to point out that in the recent review paper by Cox and colleagues, ${ }^{1}$ titled "Dipeptidyl peptidase- 4 inhibitors in the management of type 2 diabetes: safety, tolerability, and efficacy", which was published in Drug, Healthcare and Patient Safety, the authors have incorrectly described the mode of excretion for linagliptin as being predominantly renal. The correct statement should have read: "Excretion of linagliptin is predominantly nonrenal", as described in the referenced pharmacokinetic study performed by Heise and colleagues. ${ }^{2}$ A nonrenal elimination route may be important in patients with renal impairment, which is common in patients with type 2 diabetes, so this distinction may be of clinical relevance. We would be grateful if you could clarify this for your readership to help avoid any confusion.
\end{abstract}

\section{References}

1. Cox ME, Rowell J, Corsino L, Green JB. Dipeptidyl peptidase-4 inhibitors in the management of type 2 diabetes: safety, tolerability, and efficacy. Drug, Healthcare and Patient Safety. 2010;2:7-19.

2. Heise T, Graefe-Mody EU, Hüttner S, Ring A, Trommeshauser D, Dugi KA. Pharmacokinetics, pharmacodynamics and tolerability of multiple oral doses of linagliptin, a dipeptidyl peptidase-4 inhibitor in male type 2 diabetes patients. Diabetes Obes Metab. 2009;11(8):786-794.

\section{Publish your work in this journal}

Drug, Healthcare and Patient Safety is an international, peer-reviewed open-access journal exploring patient safety issues in the healthcare continuum from diagnostic and screening interventions through to treatment, drug therapy and surgery. The journal is characterized by the rapid reporting of reviews, original research, clinical, epidemiological and post-marketing surveillance studies, risk management, health literacy and educational programs across all areas of healthcare delivery. The manuscript management system is completely online and includes a very quick and fair peer-review system. Visit http://www.dovepress.com/ testimonials.php to read real quotes from published authors. 